\title{
Effects of varying radiation dosages on MMP1 expression, and MMP1 knockdown on the viability and migration of SW620 cells
}

\author{
FANG JU $^{1}, \mathrm{NA} \mathrm{LI}^{2}$, WENMING WANG ${ }^{1}$ and HAICHENG YUAN ${ }^{3}$ \\ ${ }^{1}$ Department of Oncology, Qingdao Central Hospital, Qingdao, Shandong 266042; ${ }^{2}$ Department of Respiratory Medicine, \\ Linyi People's Hospital, Linyi, Shandong 276003; ${ }^{3}$ Department of Neurology, Qingdao Central Hospital, \\ Qingdao, Shandong 266042, P.R. China
}

Received January 2, 2018; Accepted October 10, 2018

DOI: $10.3892 / \mathrm{mmr} .2019 .9899$

\begin{abstract}
Colorectal cancer (CRC), also known as bowel cancer, is one of the leading causes of cancer-associated mortality worldwide at present. The aim of the present study was to detect the effects of matrix metalloproteinase 1 (MMP1) on the viability and migration of a CRC cell line in the presence or absence of variation X-ray radiation doses. The CRC cell line, SW620, was cultured and treated with different X-ray doses (0, 0.1, 0.5, 1, 3 and 6 Gy). MMP1 expression was downregulated via the application of a specific small interfering (si)-RNA. The viability and migration of SW620 cells prior to and following transfection were detected with MTT and Transwell chamber assays, respectively. The application of siRNA transfection to silence MMP1 in SW620 cells resulted in reduced cell viability and migration $(\mathrm{P}<0.05)$. Compared with the control, the cell viability and migration of cells were significantly reduced when exposed to $0.5,1,3$, and 6 Gy X-ray radiation $(\mathrm{P}<0.05)$. In SW620 cells treated with different X-ray doses, the mRNA expression levels of MMP1 were significantly reduced $(\mathrm{P}<0.05)$. Cells treated with 0.5 Gy $\mathrm{X}$-ray exposure exhibited the lowest mRNA expression levels of MMP1 when compared with other doses of X-ray radiation. The expression of MMP1 was associated with the promotion of the viability and migration of SW620 cells. X-ray radiation with 6 Gy dosages significantly reduced cell viability when compared with the control. Thus, MMP1-targeted therapy combined with radiotherapy could be used for treating CRC.
\end{abstract}

\section{Introduction}

At present, colorectal cancer (CRC, also known as bowel cancer) is one of the leading cause of cancer-associated mortality,

Correspondence to: Dr Haicheng Yuan, Department of Neurology, Qingdao Central Hospital, 127 Siliunan Road, Qingdao, Shandong 266042, P.R. China

E-mail: haichengyuan2866@163.com

Key words: colorectal cancer, invasion, matrix metalloproteinase 1, radiation dosages, viability which is newly diagnosed in 1.4 million people and resulted in 694,000 deaths worldwide in 2012 (1). The development of CRC is characterized by the uncontrolled growth of transformed cells associated with complex interactions, including genetic alterations, environmental carcinogens and dysregulation in host immunity (2). Despite several recent developments, the therapeutic options for treatment during the metastatic stages of this disease remain limited (3). Local recurrence following the resection of CRC is difficult to treat and has been associated with severe complications. A previous study demonstrated poor prognosis following local recurrence, with a survival duration of $<18$ months (4). Therefore, therapeutic approaches that target the control of growth (metastasis, invasion and apoptosis), angiogenesis, as well as cell cycle-regulating signals, are necessary for the treatment of patients with CRC (5). Preoperative chemoradiotherapy is commonly used as a major treatment modality for advanced CRC (6). Previous studies have demonstrated that preoperative chemoradiotherapy was associated with decreased local recurrence, improved survival rate and increased anal preservation rate $(7,8)$.

Matrix metalloproteinases (MMPs) are a group of matrix-degrading proteins, which include $>22$ human zinc-dependent proteolytic enzymes $(9,10)$. MMPs produced by tumor cells or by adjacent stromal cells are involved in the metastatic process (11). Among the MMPs, MMP1 is the most ubiquitously expressed interstitial collagenase (12). Additionally, MMP1 expression in CRC cells has been reported to be associated with poor prognosis (13). Numerous studies have demonstrated the association between MMP1 and CRC (14-16); however, the effects of radiotherapy on MMP1 expression levels, cell viability and migration require further investigation.

The small bowel only tolerates limited dosages in pelvic radiotherapy (17). Bowel displacement devices have been adopted in the clinic to reduce bowel volume under high-dose pelvic radiation fields (18). Therefore, it is of great importance to understand the effects of various radiation dosages on the viability and migration of CRC cells. The present study was performed with two aims: i) To detect the effects of MMP1 on the viability and migration of CRC cells; and ii) to investigate the effects of MMP1 on cell viability and migration under various doses of X-ray radiation. The results of the present study may provide a theoretical foundation for the clinical 
application of MMP1-targeted therapy in the treatment of CRC.

\section{Materials and methods}

Cell culture. The CRC cell line SW620 was obtained from the Cell Bank of Type Culture Collection of Chinese Academy of Sciences (Shanghai, China); cells were cultured in Dulbecco's modified Eagles medium (DMEM) supplemented with $10 \%$ fetal bovine serum (FBS), $1 \%$ penicillin and $1 \%$ streptomycin (all Gibco; Thermo Fisher Scientific, Inc., Waltham, MA, USA). Cells were incubated under $5 \% \mathrm{CO}_{2}$ at a constant temperature of $37^{\circ} \mathrm{C}$ in an incubator. Following culturing for a period of time, the cells in logarithmic phase were obtained for the following experiments.

Detection of cell viability. The effects of various doses of X-ray radiation on cell viability were detected via an MTT assay. Briefly, CRC cells were plated at a density of $10^{4}$ cells/well into a 96-well plate. Cells were incubated in DMEM at $37^{\circ} \mathrm{C}$ for $48 \mathrm{~h}$ following exposure to radiation of different doses of X-ray (0, 0.1, 0.5, 1, 3 and 6 Gy). Then, cells in each well were incubated with $10 \mu \mathrm{l}$ MTT for $4 \mathrm{~h}$ at $37^{\circ} \mathrm{C}$. Following the removal of media, $100 \mu$ ld dimethyl sulfoxide was added to dissolve the formazan crystals. In addition, the optical density was measured at a wavelength of $570 \mathrm{~nm}$ using a NanoDrop spectrophotometer (Thermo Fisher Scientific, Inc., Wilmington, DE, USA).

$R N A$ isolation and reverse transcription-quantitative polymerase chain reaction ( $R T-q P C R)$. Total RNA was isolated from CRC cells with an RNA rapid extraction kit (Takara Biotechnology Co., Ltd., Dalian, China) according to the manufacturer's protocols. The concentration and purity of RNA products were measured via spectrophotometry. Then, $0.5 \mu \mathrm{g}$ total RNA was reverse transcribed into cDNA using the Prime Script ${ }^{\circledR}$ RT reagent kit (Takara Biotechnology Co., Ltd.); the reaction was incubated at $37^{\circ} \mathrm{C}$ for $15 \mathrm{~min}$, and $85^{\circ} \mathrm{C}$ for $5 \mathrm{sec}$. Using SYBR Green Master Mix (Takara Biotechnology Co., Ltd., Dalian, China), qPCR was then performed to detect the expression levels of MMP1. The $20 \mu 1$ reaction system for qPCR was: $10 \mu 1$ SYBR Premix Ex Taq (X2), $8 \mu 1$ cDNA template (diluted to a uniform level), $1 \mu 1$ forward primer $(10 \mu \mathrm{M})$, and $1 \mu \mathrm{l}$ reverse primer $(10 \mu \mathrm{M})$. Each sample had three repeats. The thermocycling conditions were as follows: $50^{\circ} \mathrm{C}$ for $3 \mathrm{~min}, 95^{\circ} \mathrm{C}$ for $3 \mathrm{~min}$, and 40 cycles of $95^{\circ} \mathrm{C}$ for $10 \mathrm{sec}$ and $60^{\circ} \mathrm{C}$ for $30 \mathrm{sec}$. A melting curve was subsequently generated. The sequences of primers used for amplification are listed in Table I. To evaluate the mRNA expression levels of MMP1, the $2^{-\Delta \Delta C q}$ method (19) was employed. $\beta$-actin was taken as the reference gene for normalizing MMP1 expression.

Small interfering (si)-RNA transfection. After the SW620 cells were digested by pancreatin (Gibco; Thermo Fisher Scientific, Inc.), centrifuged at $15,000 \mathrm{xg}$ at $4^{\circ} \mathrm{C}$ and counted, they were plated into a 6 -well plate $\left(2 \times 10^{5}\right.$ cells/well $)$ and DMEM supplemented with 10\% FBS (both Gibco; Thermo Fisher Scientific, Inc.) added. Then, 4 siRNAs were designed for silencing MMP1, and the cells were randomly divided into siRNA1-transfected cell group, siRNA2-transfected cell group, siRNA3-transfected cell group, control siRNA (Con siRNA) transfection cell group, and negative control (NC) cell group. SiRNA-mediated gene silencing of MMP1 was conducted according to the protocols of the manufacturer of Lipofectamine $2000^{\mathrm{TM}}$. Firstly, siRNA (final concentration $66 \mathrm{nM}$; GenePharma, Shanghai, China) and Lipofectamine $2000^{\mathrm{TM}}$ (Invitrogen; Thermo Fisher Scientific, Inc.) were diluted with $250 \mu 1$ Opti-Minimal Essential Medium (Gibco; Thermo Fisher Scientific, Inc.), respectively. Then, the transfection reagent was mixed with the diluted siRNA and incubated for $20 \mathrm{~min}$ at room temperature for complex formation. The complexes were added into each well for transfection with $5 \% \mathrm{CO}_{2}$ under a constant temperature of $37^{\circ} \mathrm{C}$ in an incubator. Media were changed into DMEM supplemented with 10\% FBS (both Gibco; Thermo Fisher Scientific, Inc.) after $48 \mathrm{~h}$. Untreated control cells received the same concentration of buffer, but no siRNA (NC). The silencing effects of siRNAs were detected using RT-qPCR and western blotting, and siRNA2 was employed for subsequent analysis.

Cell migration assay. Cell migration was evaluated using a 6-well Transwell filter with a polyvinylidene fluoride membrane (Merck KGaA, Darmstadt, Germany). SW620 cells were diluted by DMEM containing $0.1 \%$ bovine serum albumin (BSA; both Gibco; Thermo Fisher Scientific, Inc.) and then were seeded on 6 -well Transwell filter $\left(3 \times 10^{5}\right.$ cell/well). The Transwell filter was placed in a 24-well plate with $500 \mu$ l DMEM containing 10\% FBS (both Gibco; Thermo Fisher Scientific, Inc.), and then was cultured under $5 \% \mathrm{CO}_{2}$ at $37^{\circ} \mathrm{C}$ in an incubator. Following $24 \mathrm{~h}$ incubation, the filter was submerged in $500 \mu \mathrm{l}$ of $4 \%$ paraformaldehyde, washed twice with $500 \mu 1 \mathrm{PBS}$, stained with $0.1 \%$ crystal violet at room temperature for $10 \mathrm{~min}$, and washed with water. Prior to imaging using a fluorescence microscope (magnification, x100; 5 fields; Olympus Corporation, Tokyo, Japan), cells that had not migrated were removed with a cotton swab from the upper layer of the filter.

Western blotting. Cultured cells were washed 3 times with PBS and lysed in phenylmethanesulfonyl fluoride (Sangon Biotech Co., Ltd., Shanghai, China) on ice for $20 \mathrm{~min}$. The lysates were centrifuged at $15,000 \times \mathrm{g}$ at $4^{\circ} \mathrm{C}$ for $10 \mathrm{~min}$ and the supernatants were collected. The protein concentration was measured using a Bicinchoninic Acid protein assay kit (Sangon Biotech Co., Ltd.), with $2 \mathrm{mg} / \mathrm{ml} \mathrm{BSA}$ (Gibco; Thermo Fisher Scientific, Inc.) as the standard. Subsequently, $50 \mu \mathrm{g}$ proteins were separated by $10 \%$ SDS-PAGE and transferred onto a polyvinylidene fluoride membrane (Merck KGaA). The membranes were blocked in $5 \%$ nonfat dried milk at room temperature for $1 \mathrm{~h}$, and then incubated at $4^{\circ} \mathrm{C}$ with primary antibodies (anti-MMP1 antibody; 1:10,000; cat. no. sc-58377; Santa Cruz Biotechnology, Inc., Dallas, TX, USA and anti- $\beta$-actin antibody, 1:10,000; cat. no. 115035003; Jackson ImmunoResearch Laboratories, Inc., West Grove, PA, USA) overnight. Following washing with Tris buffered saline with Tween-20 $(1: 1,000) 4$ times, the blots were incubated with horseradish peroxidase-conjugated goat-anti-rabbit antibody (1:5,000; cat. no. 111035047 ; Jackson ImmunoResearch Laboratories, Inc.) at $37^{\circ} \mathrm{C}$ for 
Table I. Primer sequences employed in the present study.

Primer Sequence (5'-3')

MMP1 forward

MMP1 reverse

$\beta$-actin forward

$\beta$-actin reverse

\section{AAGAATGATGGGAGGCAAGT GGTTTCAGCATCTGGTTTCC GGAGATTACTGCCCTGGCTCCTA GACTCATCGTACTCCTGCTTGCTG}

MMP1, matrix metalloproteinase 1.

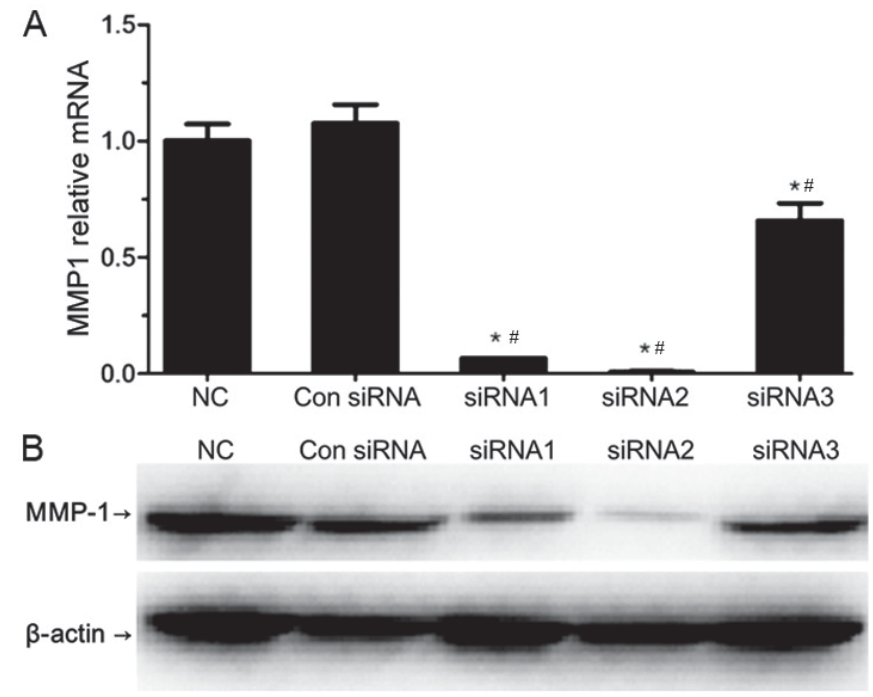

Figure 1. Effect of siRNAs on MMP1 at the (A) mRNA and (B) protein expression levels. siRNA1, siRNA2 and siRNA3 could significantly reduce MMP1 expression, especially siRNA2 which was most efficient in silencing MMP1. ${ }^{*} \mathrm{P}<0.05$ vs. NC; ${ }^{~} \mathrm{P}<0.05$ vs. Con siRNA. NC, negative control; siRNA, small interfering RNA; Con siRNA, control non-interfering RNA; MMP1, matrix metalloproteinase 1.

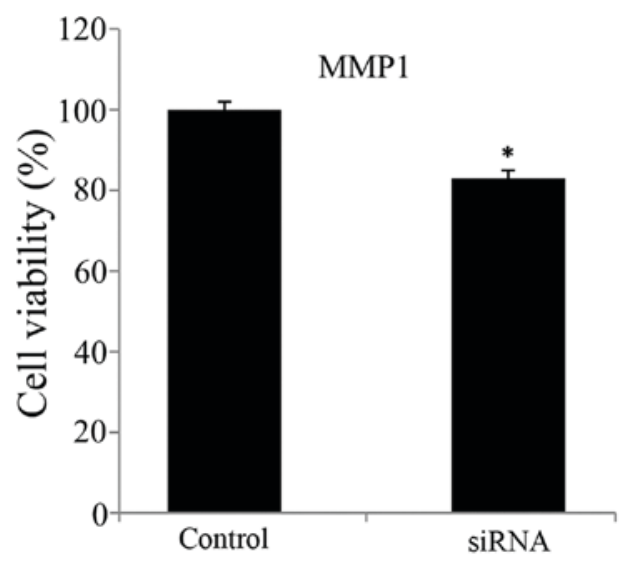

Figure 2. Viability of siRNA mediated SW620-silenced cells: The viability of siRNA-transfected SW620 cells was suppressed. ${ }^{*} \mathrm{P}<0.05$ vs. Control. MMP1, matrix metalloproteinase 1; siRNA, small interfering RNA; MMP1, matrix metalloproteinase 1 .

$1 \mathrm{~h}$, and then developed with enhanced chemiluminescence detection reagents (Merck KGaA). Visualization was performed with a gel imaging analysis system (Bio-Rad Laboratories, Inc., Hercules, CA, USA).
Statistical analysis. There were three repeats for each experiment. The data were presented as the mean \pm standard error of mean. One-way analysis of variance followed by a Bonferroni post-hoc test was applied for statistical analysis using SPSS 13.0 software (SPSS, Inc., Chicago, IL, USA). $\mathrm{P}<0.05$ was considered to indicate a statistically significant difference.

\section{Results}

Suppression of MMP1 expression levels by siRNA. The mRNA and protein expression levels of MMP1 were evaluated by RT-qPCR and western blotting, respectively (Fig. 1). All of the three designed siRNAs (siRNA1, siRNA2 and siRNA3) significantly reduced the expression levels of MMP1 when compared with the NC and Con siRNA transfection cell groups, which confirmed the success of transfection. SiRNA1 and siRNA2 resulted in a significant decrease in MMP1 expression in SW620 cells when compared with the siRNA3-transfected cell group. SiRNA2 was most efficient in silencing MMP1, and thus was selected for subsequent use.

Viability and migration of MMPI-silenced CRC cells. The viability and migration of MMP1-silenced CRC cells were presented in Figs. 2 and 3, respectively. The application of siRNA to silence MMP1 in SW620 cells resulted in significantly reduced cell viability and migration ability compared with in the control untransfected group. That is, the viability and migration ability of SW620 cells were suppressed by siRNA-induced MMP1 silencing.

Effects of radiation on cell viability and migration. The effects of various doses of X-ray exposure on SW620 cells is presented in Fig. 4. The results of the present study revealed that cell viability decreased in a dose-dependent manner following exposure to X-ray radiation. Compared with the control group, cell viability was significantly reduced following exposure to $0.5,1,3$ and 6 Gy X-ray radiation in a dose-dependent manner. The results also demonstrated that cell viability was markedly decreased under treatment with 3 and 6 Gy X-ray radiation when compared with 0.5 and $1 \mathrm{~Gy}$ treatment. These results suggested that different doses of X-ray radiation could reduce the cell viability of SW620 cells to different extents, and a higher dose of X-ray radiation had a greater inhibiting effect.

In addition, cell migration was evaluated via a Transwell assay. As presented in Fig. 5, compared with control and 0.1 Gy X-ray treated cells (Fig. 5A and B), the number of migrated cells was markedly lower in the experimental groups (Fig. 5C-E) the average number of migrated cells within 5 fields in the experimental groups $(0.5,1,3$ and 6 Gy X-ray treated cells) was significantly lower than those of the blank control and the 0.1 Gy X-ray treated cells. Therefore, different doses of X-ray radiation could markedly repress the migration of SW620 cells.

Effects of radiation on MMP1 expression. As presented in Fig. 6, the effects of radiation on the mRNA expression levels of MMP1 were determined. As a result, when exposed to X-ray radiation, the mRNA expression levels of MMP1 in SW620 cells were significantly suppressed when compared with the untreated group. The cells exposed to 0.5 Gy X-ray exhibited 

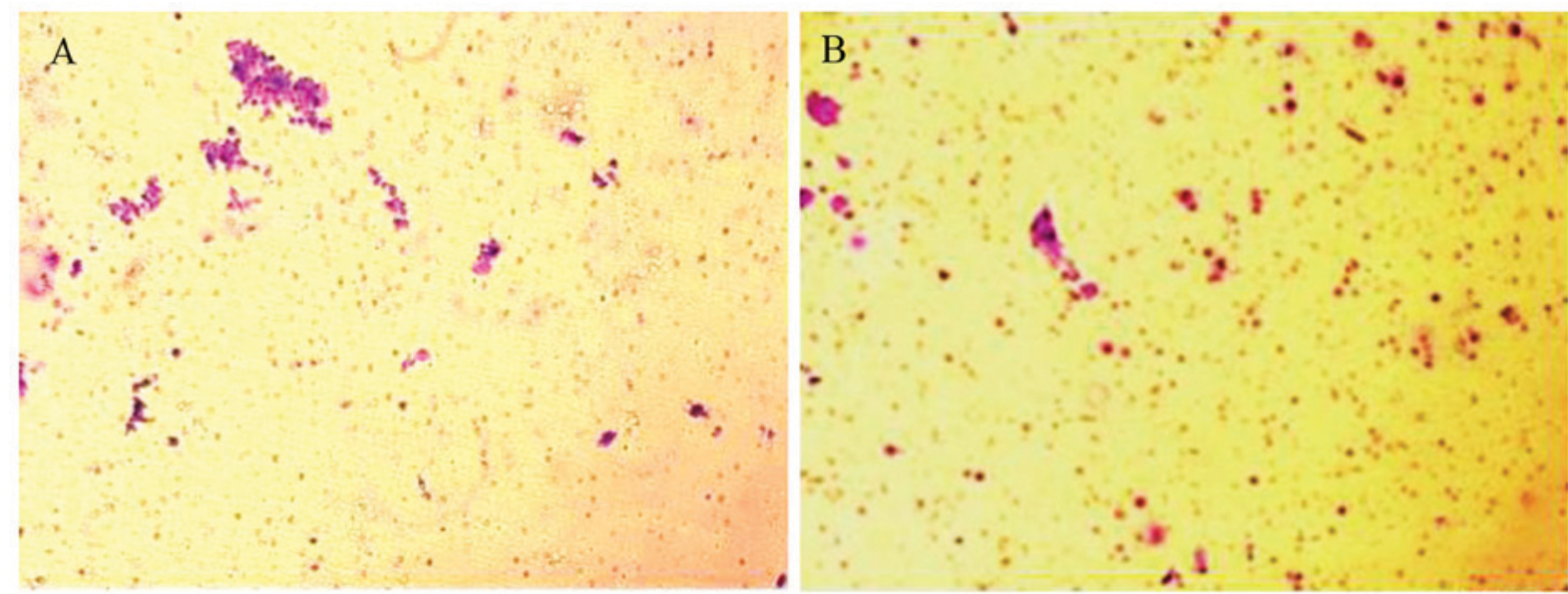

Figure 3. Migration of (A) control cells and (B) siRNA-silenced cells. The migration ability of siRNA-transfected SW620 cells was inhibited. Magnification, x100. siRNA, small interfering RNA.

the lowest mRNA expression levels of MMP1 compared with the remaining groups. With increasing doses of X-ray radiation (from 0.5 to $6 \mathrm{~Gy}$ ), the mRNA expression levels of MMP1 were markedly elevated. Thus, X-ray radiation could significantly decrease the mRNA expression levels of MMP1.

\section{Discussion}

The development of CRC is a complex process that involves multistage carcinogenesis (20). Preoperative radiotherapy is commonly used in the clinic and has been reported to be associated with decreases in recurrence rate; however, the effects of radiotherapy on CRC cells at the molecular level requires further investigation (21). MMP1 serves an important role in degrading tumor cells (22). In the present study, the SW620 cell line was selected to investigate the association between MMP1, cell viability and migration. Classified as Duke's type B level cancer, SW620 cells originate from mesenteric lymph node metastasis, with high invasive and malignancy potentials (23). Therefore, the SW620 cell line may be suitable for the detection of cell viability and migration.

MMP1 serves an important role in the degradation of collagenous extracellular matrix in a variety of physiological and pathological situations (24). The association of MMP1 and CRC has also been reported previously $(13,25)$. For example, Vogelstein et al (20) investigated the genotype of patients with CRC and revealed that MMP1 promoter polymorphisms affected the susceptibility of developing CRC due to abnormal alterations in the expression of MMP1. Additionally, MMP1 has been proposed as a prognostic factor of CRC; high MMP1 expression levels may indicate poor prognosis $(13,25)$. To detect the effects of MMP1 on cell viability and migration, MTT and Transwell assays were performed in the present study. The viability and migration of SW620 cells were significantly suppressed following MMP1 downregulation in the present study, which indicated that MMP1 may serve a key role in cell migration.

The association between preoperative radiotherapy and MMP1 in CRC cells has not been well established. MMP1 has been reported to be differentially expressed following

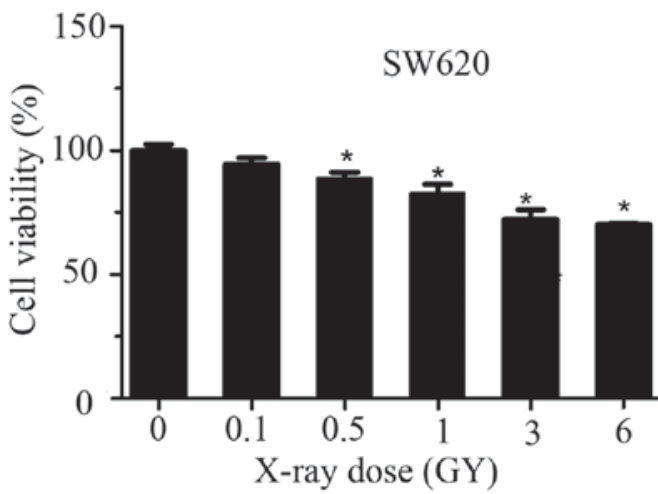

Figure 4. Effects of different X-ray doses on cell viability. Cell viability decreased in a dose-dependent manner following exposure to X-ray radiation, especially following treatment with 3 and 6 Gy $\mathrm{X}$-ray radiation. ${ }^{*} \mathrm{P}<0.05$ vs. control cells (0 Gy).

preoperative chemoradiotherapy (26). This has also been observed in patients with breast cancer, in which MMP1 protein expression levels were downregulated following preoperative radiotherapy (27). The results of present study were consistent with the aforementioned findings, which revealed that MMP1 was significantly decreased following $\mathrm{X}$-ray radiation. However, from gene expression profile studies, alterations in the expression of MMP1 have not been observed in patients with CRC following radiotherapy $(28,29)$. This may be due to varying sensitivities of radiation in different growth stages of tumors. Therefore, it appears necessary to consider tumor stages when combining MMP1-targeted therapy with current radiotherapy regimens.

Radiation dosage serves an important role in radiotherapy for patients with cancer (30). In the present study, it was reported that the mRNA expression levels of MMP1 varied in response to different doses of X-ray radiation. The results indicated that radiation dosage was associated with gene expression levels, which may affect the therapeutic efficiency. There is limited information regarding the radiation dosage of preoperative chemoradiotherapy on CRC. A high radiation dose ( $45 \mathrm{~Gy}$ ) has been reported to affect the pathological complete response level of patients with rectal cancer (31). A previous study investigated 

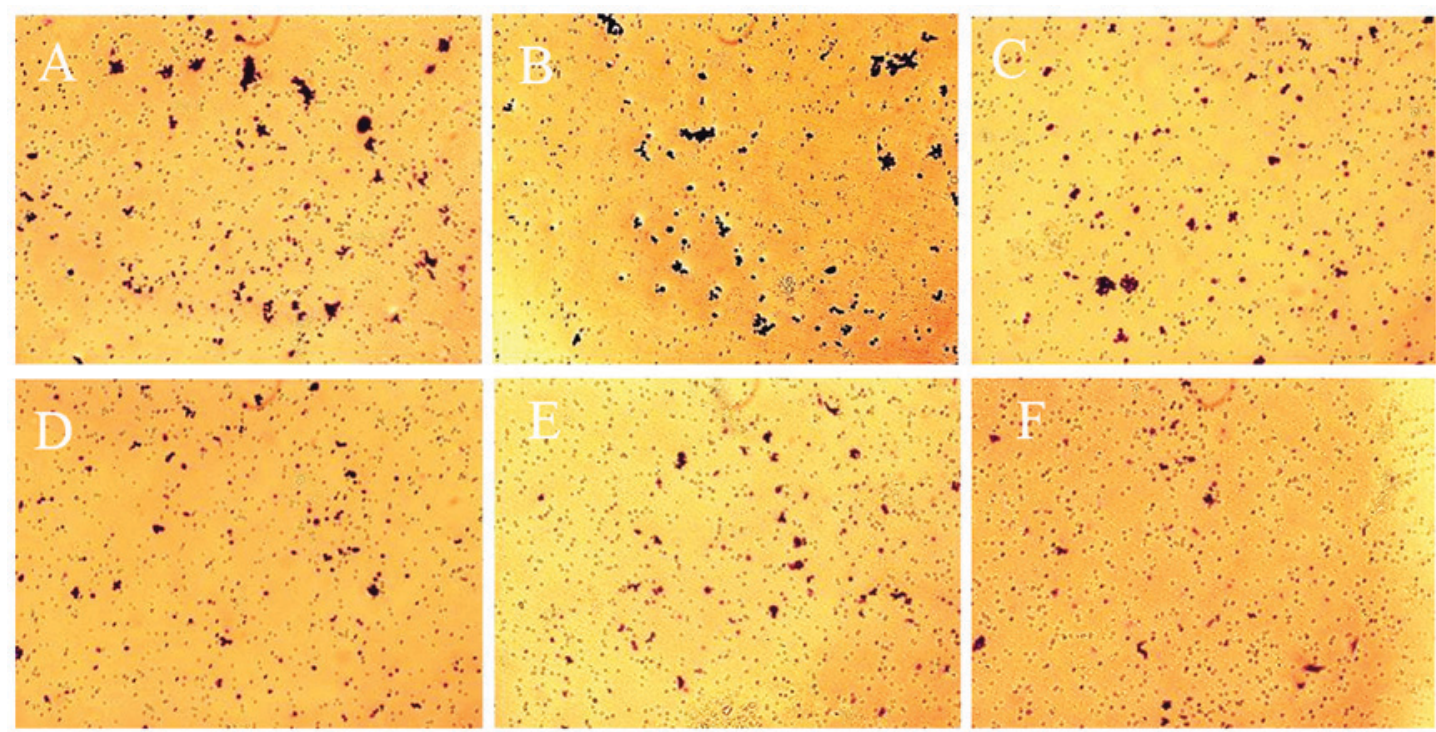

Figure 5. Cell migration as observed by crystal violet staining. The migration of SW620 cells treated by $0.5,1,3$, and 6 Gy X-ray radiation was markedly inhibited. Magnification, x100. (A) Blank control, 0 Gy X-ray radiation. (B) 0.1 Gy X-ray radiation. (C) 0.5 Gy X-ray radiation. (D) 1 Gy X-ray radiation. (E) 3 Gy X-ray radiation. (F) 6 Gy X-ray radiation.

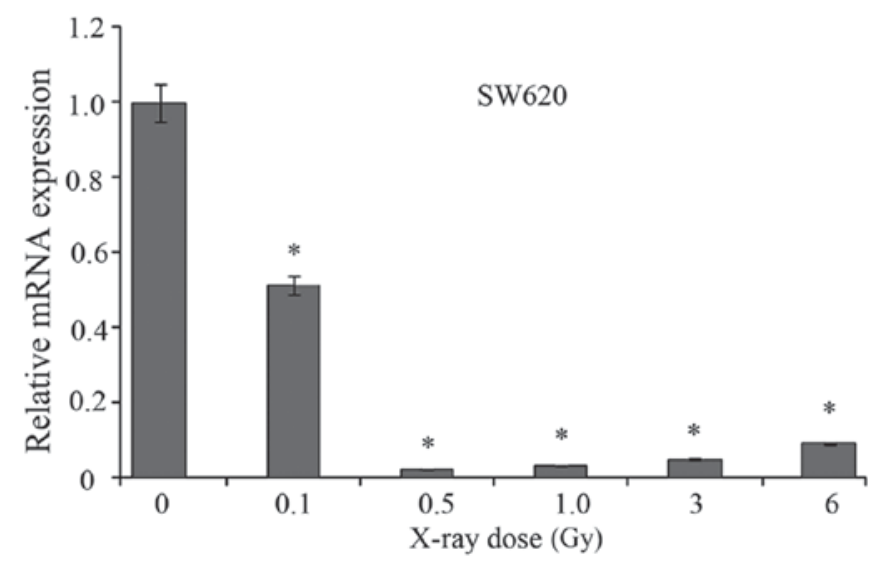

Figure 6. Relative mRNA expression levels of matrix metalloproteinase 1 in SW620 cells when exposed to different doses of X-ray radiation. X-ray radiation significantly decreased the mRNA expression levels of MMP1 and 0.5 Gy X-ray radiation had the greatest inhibiting effect. ${ }^{*} \mathrm{P}<0.05$ vs. 0 Gy.

the effects of X-ray doses ( $0,2,4,6$ and $8 \mathrm{~Gy})$ on the expression of microRNA (miR) -221 and p57 $7^{\mathrm{kip} 2}$ in CRC cells, which revealed that radiation dose can affect the miR-221/p57kip2 pathway (27). This may enhance the radiosensitivity of CRC cells (32). In the present study, the mRNA expression levels of MMP1 were significantly decreased in SW620 cells when exposed to X-ray radiation. Additionally, the viability and migration of SW620 cells prior to MMP1-silencing were significantly reduced in a dose-dependent manner. The results of the present study may provide novel insight into the radiotherapy of CRC in the clinic.

In conclusion, expression of MMP1 was associated with the promotion of the viability and migration of SW620 cells. X-ray radiation of 6 Gy significantly reduced cell viability. It also appears necessary to consider tumor stages when applying combined MMP1-targeted therapy with current radiotherapy regimens. In the future, investigation may be conducted with in vivo models or samples obtained from patients with CRC.

\section{Acknowledgements}

Not applicable.

\section{Funding}

No funding was received.

\section{Availability of data and materials}

The datasets used and/or analyzed during the current study are available from the corresponding author on reasonable request.

\section{Authors' contributions}

FJ conceived and designed the study; NL acquired the data; WW analyzed and interpreted the data; HY performed statistical analysis; FJ and NL drafted the manuscript, and WW and HY revised the manuscript for important intellectual content. All authors read and approved the final manuscript.

\section{Ethics approval and consent to participate}

Not applicable.

\section{Patient consent for publication}

Not applicable.

\section{Competing interests}

The authors declare that they have no competing interests.

\section{References}

1. McGuire S: World cancer report 2014. Geneva, Switzerland: World Health Organization, International Agency for Research on Cancer, WHO press, 2015. Adv Nutr 7: 418-419, 2016. 
2. Fearon ER and Vogelstein B: A genetic model for colorectal tumorigenesis. Cell 61: 759-767, 1990.

3. Lange F, Franz B, Maletzki C, Linnebacher M, Hühns M and Jaster R: Biological and molecular effects of small molecule kinase inhibitors on low-passage human colorectal cancer cel lines. Biomed Res Int 2014: 568693, 2014.

4. Holm T, Cedermark B and Rutqvist LE: Local recurrence of rectal adenocarcinoma after 'curative' surgery with and without preoperative radiotherapy. Br J Surg 81: 452-455, 1994.

5. Hanahan D and Weinberg RA: The hallmarks of cancer. Cell 100 57-70, 2000.

6. Park IJ and Yu CS: Current issues in locally advanced colorecta cancer treated by preoperative chemoradiotherapy. World J Gastroenterol 20: 2023-2029, 2014.

7. Braendengen M, Tveit KM, Berglund A, Birkemeyer E, Frykholm G, Påhlman L, Wiig JN, Byström P, Bujko K and Glimelius B: Randomized phase III study comparing preoperative radiotherapy with chemoradiotherapy in nonresectable rectal cancer. J Clin Oncol 26: 3687-3694, 2008.

8. Kao PS, Chang SC, Wang LW, Lee RC, Liang WY, Lin TC, Chen WS, Jiang JK, Yang SH, Wang HS and Lin JK: The impact of preoperative chemoradiotherapy on advanced low rectal cancer. J Surg Oncol 102: 771-777, 2010.

9. Parsons SL, Watson SA, Brown PD, Collins HM and Steele RJ: Matrix metalloproteinases. Br J Surg 84: 160-166, 1997.

10. Visse R and Nagase H: Matrix metalloproteinases and tissue inhibitors of metalloproteinases: Structure, function, and biochemistry. Circ Res 92: 827-839, 2003.

11. Zucker S and Vacirca J: Role of matrix metalloproteinases (MMPs) in colorectal cancer. Cancer Metastasis Rev 23: 101-117, 2004.

12. Arakaki PA, Marques MR and Santos MC: MMP-1 polymorphism and its relationship to pathological processes. J Biosci 34 313-320, 2009

13. Murray GI, Duncan ME, O'Neil P, Melvin WT and Fothergill JE: Matrix metalloproteinase-1 is associated with poor prognosis in colorectal cancer. Nat Med 2: 461-462, 1996

14. Zinzindohoué F, Lecomte T, Ferraz JM, Houllier AM, Cugnenc PH, Berger A, Blons H and Laurent-Puig P: Prognostic significance of MMP-1 and MMP-3 functional promoter polymorphisms in colorectal cancer. Clin Cancer Res 11: 594-599, 2005.

15. Bendardaf R, Buhmeida A, Ristamäki R, Syrjänen K and Pyrhönen S: MMP-1 (collagenase-1) expression in primary colorectal cancer and its metastases. Scand J Gastroenterol 42 : $1473-1478,2007$.

16. Han G, Wei Z, Lu Z, Cui H, Bai X, Ge H and Zhang W: Association between matrix metalloproteinase $1-1607$ 1G $>2 \mathrm{G}$ polymorphism and cancer risk: A meta-analysis including 19706 subjects. Int J Clin Exp Med 7: 2992-2999, 2014.

17. Drzymala M, Hawkins M, Henrys A, Bedford J, Norman A and Tait D: The effect of treatment position, prone or supine, on dose-volume histograms for pelvic radiotherapy in patients with rectal cancer. Br J Radiol 82: 321-327, 2009.

18. Kim JY, Kim DY, Kim TH, Park SY, Lee SB, Shin KH, Pyo H, Kim JY and Cho KH: Intensity-modulated radiotherapy with a belly board for rectal cancer. Int J Colorectal Dis 22: 373-379, 2007.

19. Livak KJ and Schmittgen TD: Analysis of relative gene expression data using real-time quantitative PCR and the 2(-Delta Delta C(T)) method. Methods 25: 402-408, 2001.
20. Vogelstein B, Fearon ER, Hamilton SR, Kern SE, Preisinger AC, Leppert M, Nakamura Y, White R, Smits AM and Bos JL: Genetic alterations during colorectal-tumor development. N Engl J Med 319: 525-532, 1988.

21. Häfner MF and Debus J: Radiotherapy for colorectal cancer: Current standards and future perspectives. Visc Med 32: 172-177, 2016.

22. Tahara K, Mimori K, Iinuma H, Iwatsuki M, Yokobori T, Ishii H, Anai H, Kitano S and Mori M: Serum matrix-metalloproteinase-1 is a bona fide prognostic marker for colorectal cancer. Ann Surg Oncol 17: 3362-3369, 2010.

23. Teran BL and Thomas J: Antimycin induces apoptosis in rapamycin resistant SW620 colorectal cancer cells. FASEB J 27: 793-798, 2013

24. Westermarck J and Kähäri VM: Regulation of matrix metalloproteinase expression in tumor invasion. FASEB J 13: 781-792, 1999.

25. Langenskiöld M, Ivarsson ML, Holmdahl L, Falk P, Kåbjörn-Gustafsson C and Angenete E: Intestinal mucosal MMP-1-a prognostic factor in colon cancer. Scand J Gastroenterol 48: 563-569, 2013.

26. Nishioka M, Shimada M, Kurita N, Iwata T, Morimoto S, Yoshikawa K, Higashijima J and Miyatani T: Gene expression profile can predict pathological response to preoperative chemoradiotherapy in rectal cancer. Cancer Genomics Proteomics 8: 87-92, 2011.

27. Artacho-Cordón F, Ríos-Arrabal S, Lara PC, Artacho-Cordón A, Calvente I and Núñez MI: Matrix metalloproteinases: Potential therapy to prevent the development of second malignancies after breast radiotherapy. Surg Oncol 21: 143-151, 2012.

28. Angenete E, Oresland T, Falk P, Breimer M, Hultborn R and Ivarsson ML: Preoperative radiotherapy and extracellular matrix remodeling in rectal mucosa and tumour matrix metalloproteinases and plasminogen components. Acta Oncol 48: 1144-1151, 2009

29. Supiot S, Gouraud W, Campion LC, Jezéquel P, Buecher B Charrier J, Heymann MF, Mahé MA, Rio E and Chérel M: Early dynamic transcriptomic changes during preoperative radiotherapy in patients with rectal cancer: A feasibility study. World J Gastroenterol 19: 3249-3254, 2013.

30. Jo S, Choi Y, Park SK, Kim JY, Kim HJ, Lee YH, Oh WY, Cho H and Ahn KJ: Efficacy of dose-escalated radiotherapy for recurrent colorectal cancer. Ann Coloproctol 32: 66-72, 2016

31. Sanghera P, Wong DW, McConkey CC, Geh JI and Hartley A: Chemoradiotherapy for rectal cancer: An updated analysis of factors affecting pathological response. Clin Oncol (R Coll Radiol) 20: 176-183, 2008.

32. Sun K, Zhang X, Deng H, et al: Effects of X-ray dose on expression of microRNA-221 and p57 (kip2) in human colorectal carcinoma cells. Cancer Res Prev Treat 40: 921-924, 2013.

This work is licensed under a Creative Commons Attribution-NonCommercial-NoDerivatives 4.0 International (CC BY-NC-ND 4.0) License. 